\title{
Evaluace výukového programu
}

\author{
Karolína Hornová \\ Envigogika 2007/II/3 - Recenzované články/ Reviewed Papers \\ Publikováno/Published 30. 12. 2007 \\ DOI: http://dx.doi.org/10.14712/18023061.22
}

\begin{abstract}
Abstrakt:
Článek se zabývá evaluací výukového programu Ochránci planety, vytvořeného podle metodiky výchovy o Zemi. Na konkrétním příkladě ukazuje metodické problémy, které s evaluací výukových programů mohou být spojeny.
\end{abstract}

\section{Klíčová slova:}

Evaluace, výukový program, environmentální výchova, environmentální postoje, Výchova o Zemi

\begin{abstract}
:
The article is concerned with an evaluation of learning programs of environmental education. Through a concrete example it shows the possibility of assessing and quantifying students' change in attitude towards the environment during participation in the created learning program, which was based on Earth Education.

It builds on the work of the Institute for Earth Education which is working both on creating learning programs and evaluation methodology for achieving defined outcomes. The review of the Institute's research describes the positive influence on knowledge, attitudes and behaviour of participants in their programs (Sunship Earth, Earthkeepers), but methodology used has not yet been published. This paper surveys the evaluation of the learning program Earth Guardians created by the author and based on ideas of Earth Education. The target group comprises secondary school students (11-13 years old). In more detail it is focused on evaluation of changes in values and attitudes of participating students. For the research, the modified instrument for measurement of environmental attitudes - The New Environment Paradigm scale - was used.

The students who participated in the program accomplished better results in awareness of environmental issues, but a significant difference was only in the statement "Me and my damage to the environment" It is necessary to continue with the research, by finding a representative sample control group. Only then we can decide if our methodology will be useful for the evaluation of learning programs of environmental education.
\end{abstract}




\section{Key words:}

Evaluation, learning programme, environmental education, environmental attitude, Earth Education 


\section{Úvod}

Stále více škol realizuje environmentální výchovu prostřednictvím nabízených výukových programů neziskových organizací, a stejně tak jako produkty vyrobené v jiných odvětvích podstupují výsledky určitou kontrolu kvality, i výukové programy by měly projít obdobnou zkouškou. Každého tvưrce programu by mělo zajímat, zda realizací dosáhl vytyčených cílů, v našem případě zda došlo ke změně v myšlení a chovaní žákư tak, aby se chovali co nejšetrněji k životnímu prostředí. Jsou-li žáci a studenti výukovými programy $v$ tomto směru nepoznamenáni, je to, jako bychom snědli jablko, které nám nedodá žádné živiny. Proto současné volání po evaluaci programů environmentální výchovy není zbytečné, právě naopak, je nezbytné. Je potřeba zdůraznit, jak důležitý je $v$ tomto případě poctivý a kritický přístup a zároveň, jak náročné může být postihnutí změny v oblasti afektivních cílů. $V$ tomto článku jsme se pokusili o evaluaci výukového programu pro žáky pátých až sedmých tříd základních škol.

\section{Hodnocení v environmentální výchově}

Hodnocení v environmentální výchově (EV) by se po vzoru hodnocení ve vyučování dalo definovat jako vyjádření výsledkư výchovného působení programu a činnosti žáka ve vztahu k plánovanému cíli (Dvořáková, 2007, s. 243). Souvislost evaluace s vytyčenými cíli je tedy zřejmá. Cíle environmentální výchovy byly definovány při mezinárodní konferenci v Tbilisi v roce 1977.

Cíle environmentální výchovy:

- podporovat uvědomění a zájem o ekonomickou, sociální, politickou a ekologickou vzájemnou závislost městských a zemědělských oblastí

- poskytnout každému př́ležitost získat znalosti, přijmout hodnoty, postoje, závazky a dovednosti chránit a zlepšovat prostředí

- $\quad$ vytvořit nové vzorce chování jedinců, skupin a celé společnosti, které jsou šetrné $\mathrm{k}$ prostředí

Pro konkrétní programy je tedy třeba stanovit si cíle jak z oblasti kognitivních, tak afektivních, ale především i z oblasti konkrétních změn v chování jedinců na naší planetě, protože to je to, co může oddálit úplnou devastaci současné biosféry. S pưvodními cíli EV pracuje metodika Výchovy o Zemi. Zároveň se snaží vytvořit komplexní nástroj pro evaluaci výukových programů.

\section{Výchova o Zemi a evaluace jejich programů}

Výchova o Zemi (Earth Education) vznikla v šedesátých letech minulého století ve Spojených státech jako reakce na některé nedostatky a problémy stávající environmentální výchovy, kterými jsou zejména nedostatečně definované cíle, zaměření na ekologické problémy a katastrofy, absence strukturovaných výukových programů a nedostatečný zájem o změnu životního stylu vzdělávaných osob. Duchovním otcem této alternativy environmentální výchovy je Steve van Matre, který spolu se svými kolegy navrhl ucelenou metodiku Výchovy o Zemi a vytvořil výukové programy pro různé věkové kategorie. Za opravdové výukové programy považují vzniklou sérii cílených pečlivě vytvořených učebních zkušeností, kde jedna navazuje a staví na druhé, a které stále mají na zřeteli dosažení specifických výsledků (Van Matre, 1999).

Výchova o Zemi je proces, který má pomáhat lidem žít v harmonickém a radostném vztahu s prírodním světem (Van Matre, 1999). Autoři předpokládají, že žáci nezmění svůj 
životní styl pouze na základě získaných poznatků o globálním ekosystému, systematických znalostí z biologie, geologie apod. Výukové programy Výchovy o Zemi se zaměřují na tři složky osobnosti žáka - na jeho hlavu, srdce a ruce, tedy jak na základní porozumění ekologickým systémům, společenstvům naší planety (tok energie, koloběh minerálních látek, vzájemné vztahy, změny životních forem), tak na získávání pozitivních zkušeností $\mathrm{z}$ kontaktu $\mathrm{s}$ prírodou, vytváření pozitivního vztahu $\mathrm{k}$ Zemi a $\mathrm{v}$ neposlední řadě mají pomoci změnit cestu jejich života na Zemi (Van Matre,1999). Jako účinné prostředky používají aktivity, které jsou koncipované jako edukační dobrodružství, plné jakési tajemné kouzelné atmosféry, která žáky do učení vtáhne. Také využívají učební model I-A-A, který zahrnuje získání poznatků (Informování), jejich osvojení prostřednictvím nějaké aktivity (Asimilaci - zpracování informace) a využití (Aplikaci). Dalším z požadavků na "opravdové" výukové programy Výchovy o Zemi je dưraz na pobyt žáků $v$ prírodě, vnímání pomocí všech smyslů a vytváření pozitivních zkušeností z kontaktu s prírodou, při těchto aktivitách hraje významnou roli samota (podle Van Matre, 1999).

Tým pro výzkum a evaluaci Výchovy o Zemi vznikl na Arizonské Univerzitě v roce 2003. Jeho projekty se zaměřují na porozumění ekologickým principům, vnímání, a dále na aktivity tisíců studentů, učitelủ a organizátorů, kteř́ jsou zahrnuti do realizace programů Výchovy o Zemi. Dlouhodobý projekt se zajímá o to, jaký dopad mají programy na zmíněné oblasti osobnosti žákủ během čtyř až pěti let. Pracovníci $k$ tomu používají tři typy dotazníků, které jsou zaměřené na porozumění (the Ecological Concept Questionnaire), na vnímání (the Environment Questionnaire) a na chování (the Follow-Thought Questionnaire) (Johnson, 2005). Práce na výzkumech a zároveň i na jejich metodice a tedy i na konečné podobě stále pokračuje, proto bohužel texty jednotlivých dotazníků nejsou ještě publikovány. Výzkumy na programech Earthkeepers a Sunship Earth zatím ukazují, že si žáci osvojí znalosti a porozumění základním ekologickým pojmům a jejich vědomosti jsou dlouhodobé. Rovněž $v$ oblasti proenvironmentálního vnímání vykazuje většina studentů zlepšení, které je $v$ delším časovém horizontu stabilní (Johnson, 2005). Starší výzkumy (Eagles, 1999, Johnson 2004) ukazují posun $v$ oblasti vědomostí, ale změny $v$ oblasti postojů nejsou zcela zřejmé.

\section{Výukový program Ochránci planety}

Výukový program Ochránci planety vychází z metodiky programů Výchovy o Zemi. Jedná se o tř́denní pobytový program na chalupě ve vhodné lokalitě, který je doplněn o několik úkolů, jež žáci pod vedením učitele plní po př́ijezdu. Koncepce programu je inspirována programem Earthkeepers (Van Matre, 1988). Zastoupení tř́ nezbytných složek Výchovy o Zemi, tj. porozumění základním ekologickým pojmům, vnímání pocitů spojených $s$ pobytem $v$ př́rodě a zpracování získaných znalostí a prožitků do postojů a vlastního chování, reprezentuje $v$ programu Earthkeepers získávání klíčů (KEYS) od uzamčených truhliček. U Ochránců planety byla vytvořena analogie (viz Tab.1) objevování hesla z motta a loga na zapečetěné desky (HRSTi). Spolu s tajemnými iniciálami M.E. (resp. M.Z.) a neúplným obrázkem stromu je tvoří organizátor (organiser), který pomáhá žákům orientovat se, $v$ jaké fázi programu se nacházejí. Legenda, záhadné desky a deník zde mají motivační funkci, jejich úkolem je získat pozornost, a proto je v souladu s definicí Hakra $(2005$, s. 23) můžeme označit původním pojmem "háček" (hook). Jednotlivé aktivity jsou převzaty, přeloženy a upraveny z publikací Earthkeereps (Van Matre, 1988) a Sunship Earth (Van Matre, 1979), některé další jsou autorské. 
Tabulka 1. Analogie

\begin{tabular}{|l|l|l|l|l|}
\hline $\mathbf{K}$ & knowledge & $\mathbf{H}$ & hlava & znalosti \\
\hline $\mathbf{E}$ & experience & $\mathbf{R}$ & ruce & vlastní zkušenost \\
\hline $\mathbf{Y}$ & yourself & $\mathbf{S}$ & srdce & $\begin{array}{l}\text { Jak to cítíš? Co uděláš z vlastního } \\
\text { presvědčení? }\end{array}$ \\
\hline $\mathbf{S}$ & sharing & $\mathbf{T i}$ & $\begin{array}{l}\text { tisíce } \\
\text { dalších }\end{array}$ & sdílení s dalšími lidmi \\
\hline
\end{tabular}

První den programu je zaměřen zejména na porozumění některým základním ekologickým principům. K dosažení tohoto cíle jsou použity didaktické hry z Pojmových stezek z programu Sunship Earth (Van Matre, 1979), které jsou zaměřené na pochopení toku energie a koloběhu látek $v$ ekosystému; dále například kooperativní desková hra na fotosyntézu. Večer se žáci věnují výrobě drobných předmětů a zároveň hledají cesty, jak se jednotlivé suroviny dostaly až $\mathrm{k}$ nim, a jak to souvisí $\mathrm{s}$ tokem energie a koloběhem látek. Během druhého dne je kladen velký důraz na pobyt v přírodě, smyslové vnímání. Celodenní výprava je koncipovaná jako objevná cesta, kde mají žáci možnost naučit se dívat na svět jinak, než byli dosud zvyklí - intenzivněji a všemi smysly. Mimo prožitkových aktivit jsou zařazeny i úkoly a didaktické hry, které podporují pochopení vzájemných souvislostí a vztahů v ekosystému. Po návratu následuje sázení stromků, tedy konkrétní počin ve prospěch životního prostředí. Také je vyhrazen prostor a čas, aby mohli několikrát za program být sami obklopeni přírodou na svém magickém místě (Van Matre, 1979) a čerpat energii z okolního prostředí. Třetí den by měl žáky motivovat k pokračování v programu i po skončení pobytu a tedy ke změně špatných vzorců chování, jež jsou součástí životního stylu žáků. K tomu by jim měly napomáhat aktivity po skončení pobytové části programu, tedy hlavně vyplňování "zeleného života". Žáci každý den pomocí formuláře, kde jsou uvedeny některé návyky typické pro environmentální chování, zhodnotí, jak šetrně se chovali k naší planetě.

\section{Realizace a evaluace programu}

Realizace programu Ochránci planety proběhla 4. - 6. června 2007 na Mariánskohorských boudách $v$ Jizerských horách ve spolupráci se Společností přátel přírody. Pobytu se zúčastnilo 16 žákư ze dvou tříd (6.A a 7.A ze ZŠ U Soudu, Liberec). Program je navržen pro třídní kolektiv, proto bohužel nemohly být plně realizovány všechny části programu, zejména úkoly, které měly následovat po skončení programu. Součástí realizace programu byla i komplexní evaluace, která jednak zahrnovala kvalitativní hodnocení aktivit, které vychází z pozorování během programu a bude využito ke změnám, jež by měly vést ke zkvalitnění výukového programu. Kvalitativní hodnocení bylo také použito při hodnocení oblasti pocitů a emocionálních prožitků žáků. Tento článek se podrobněji zabývá kvantitativním hodnocením možných změn $v$ oblasti environmentálních postojů. 


\section{Metodika evaluace dosažení cílư v oblasti environmentálních postojů}

Pro oblast postojů byly v programu Ochránci planety definovány tyto cíle:

Žák:

- zažije příjemné pocity při kontaktu s přírodou, které povedou $k$ upevnění kladného vztahu $k$ prírodě

- přijme nové postoje (resp. upevní své vlastní), které směřují ke změně životního stylu, který bude ohleduplnější k životnímu prostředí

Evaluace dosažení afektivních cílů byla provedena na skupině 33 žáků ze ZŠ U Soudu v Liberci - z toho 14 žáků prošlo výukovým programem Ochránci planety a dalších 19 žáků ze stejných tříd posloužilo jako kontrolní skupina.

Pro výzkum změn v oblasti environmentálních postojů byl použit dotazník "Jaký je můj názor?", který vznikl úpravou nástroje pro měření environmentální gramotnosti, tzv. Rozšířené NEP/DSP (Nové environmentální paradigma/Dominantní společenské paradigma) škály proenvironmentálních postojů (Činčera, Štěpánek, 2007). Z celkového počtu šestnácti položek bylo vybráno deset a jejich formulace byla upravena vzhledem $k$ věkové skupině. NEP škála používá Likertovu (sedmibodovou) stupnici míry souhlasu s tvrzeními, charakteristickými pro NEP či DSP. Při evaluaci programu Ochránci planety byla použita pětibodová stupnice, která byla navíc zpracována graficky, aby byla míra souhlasu vyjádřena vizuálně. Cílem šetření bylo ověřit následující hypotézy:

HO: Žáci, kteří se zúčastnili výukového programu Ochránci planety, zastávají častěji proenvironmentální postoje než studenti, kteří se programu nezúčastnili.

H1 (H2, H3, H4, H5, H6, H7, H8, H9, H10): Žáci, kteří se zúčastnili výukového programu Ochránci planety, zastávají u tvrzení $1(2,3,4,5,6,7,8,9$, 10) častěji proenvironmentální postoj než studenti, kteří se programu nezúčastnili.

\section{Dotazník "Jaký je můj názor?"}

1. Měl bych žít v souladu s přírodou, aby i pro další lidi byla Země obyvatelná.

2. I já, svým chováním, poškozuji životní prostředí.

3. Rozvinutý mozek dává nám lidem právo, abychom vládli zbytku př́rody.

4. Lidé mají právo upravovat prrírodní prostředí, jak potřebují.

5. Nové vynálezy zachrání Zemi před dalšími ekologickými katastrofami.

6. Zvířata a rostliny mají stejná práva existovat, jako lidé.

7. Přírodní zdroje by měly být využívány spíše pro uspokojení základních životních potřeb (jídlo, pití, střecha nad hlavou a podobně) než pro život v přepychu.

8. Moje jednání nemá žádný zásadní vliv na změny $v$ ekosystémech na jiných světadílech.

9. Lidstvu nehrozí žádná obrovská ekologická katastrofa, která by zasáhla celou planetu.

10. Když jsem v přírodě, cítím se příjemně. 
Při zpracování dotazníků byly odpovědím na jednotlivá tvrzení přiřazeny body od -2 do 2 (viz Tab. 2) v závislosti na míře souhlasu se spíše proenvironmentálním postojem (položka 1, 2, 6, 7, 10) nebo míře nesouhlasu s opačným postojem (položka 3, 4, 5, 8, 9). Hodnota 0 tedy představuje neutrální postoj.

Tabulka 2.

\begin{tabular}{|l|l|l|l|l|l|}
\hline míra souhlasu & \multirow{2}{*}{$\begin{array}{l}\text { vůbec } \\
\text { nesouhlasím }\end{array}$} & $\begin{array}{l}\text { spíše } \\
\text { nesouhlasím }\end{array}$ & nevím & $\begin{array}{l}\text { spíše } \\
\text { souhlasím }\end{array}$ & $\begin{array}{l}\text { úplně } \\
\text { souhlasím }\end{array}$ \\
\hline $1,2,6,7,10$ & -2 & -1 & 0 & 1 & 2 \\
\hline $3,4,5,8,9$ & 2 & 1 & 0 & -1 & -2 \\
\hline
\end{tabular}

Výsledky evaluace dosažení cílů v oblasti environmentálních postojů

U respondentů v obou skupinách převládaly u většiny výroků proenvironmentální postoje (viz Obr. 1). Celkově žáci, kteří se zúčastnili programu Ochránci planety, dosáhli mírně lepších výsledků než kontrolní skupina (viz Tab. 3, Tab. 4, Obr. 1). Statisticky významný rozdíl, který byl zjištóván Mann-Whitneyho U-testem, se ve prospěch účastníků programu projevil pouze u tvrzení 2 ("I já svým chováním poškozují životní prostředí."). Naopak u tvrzení 8 ("Moje jednání nemá žádný zásadní vliv na změny v ekosystémech na jiných světadílech."), vykazovala kontrolní skupina oproti účastníkům programu více proenvironmentální postoj (viz Obr. 2).

Tabulka 3.

\begin{tabular}{|l|l|l|}
\hline \multirow{2}{*}{\multicolumn{2}{|c||}{ tvrzení }} & \multicolumn{2}{l|}{$\begin{array}{l}\text { průmèrné } \\
\text { hodnoty }\end{array}$} & MHB & KS \\
\hline 1. & 0,64 & 0,53 \\
\hline 2. & 1,00 & $-0,11$ \\
\hline 3. & 0,57 & 0,68 \\
\hline 4. & 0,50 & 0,74 \\
\hline 5. & 0,64 & 0,63 \\
\hline 6. & 1,29 & 1,26 \\
\hline 7. & 0,79 & 0,74 \\
\hline 8. & $-0,36$ & 0,47 \\
\hline 9. & 0,36 & 0,26 \\
\hline 10. & 1,07 & 0,74 \\
\hline celkem & $\mathbf{6 , 5 0}$ & $\mathbf{5 , 9 5}$ \\
\hline
\end{tabular}

MHB - účastníci výukového programu Ochránci planety pořádaného na Mariánskohorských boudách v Jizerských horách

KS - kontrolní skupina 
Tabulka 4.

\begin{tabular}{|c|c|c|c|c|c|c|c|c|c|c|c|c|c|c|c|c|c|c|}
\hline \multirow{2}{*}{\multicolumn{5}{|c|}{$\begin{array}{l}\text { dosažený počet } \\
\text { bodů v dotazníku }\end{array}$}} & \multicolumn{14}{|c|}{ účastníci výukového programu } \\
\hline & & & & & 13 & 7 & & 0 & 7 & 0 & 11 & 0 & 13 & 13 & 8 & 3 & 2 & 7 \\
\hline \multicolumn{19}{|c|}{ kontrolní skupina žáků } \\
\hline 4 & 10 & -1 & -1 & 2 & 18 & - & & 16 & 0 & 8 & 11 & -3 & 8 & 4 & 3 & 5 & 15 & 7 \\
\hline
\end{tabular}

\section{Obrázek 1.}

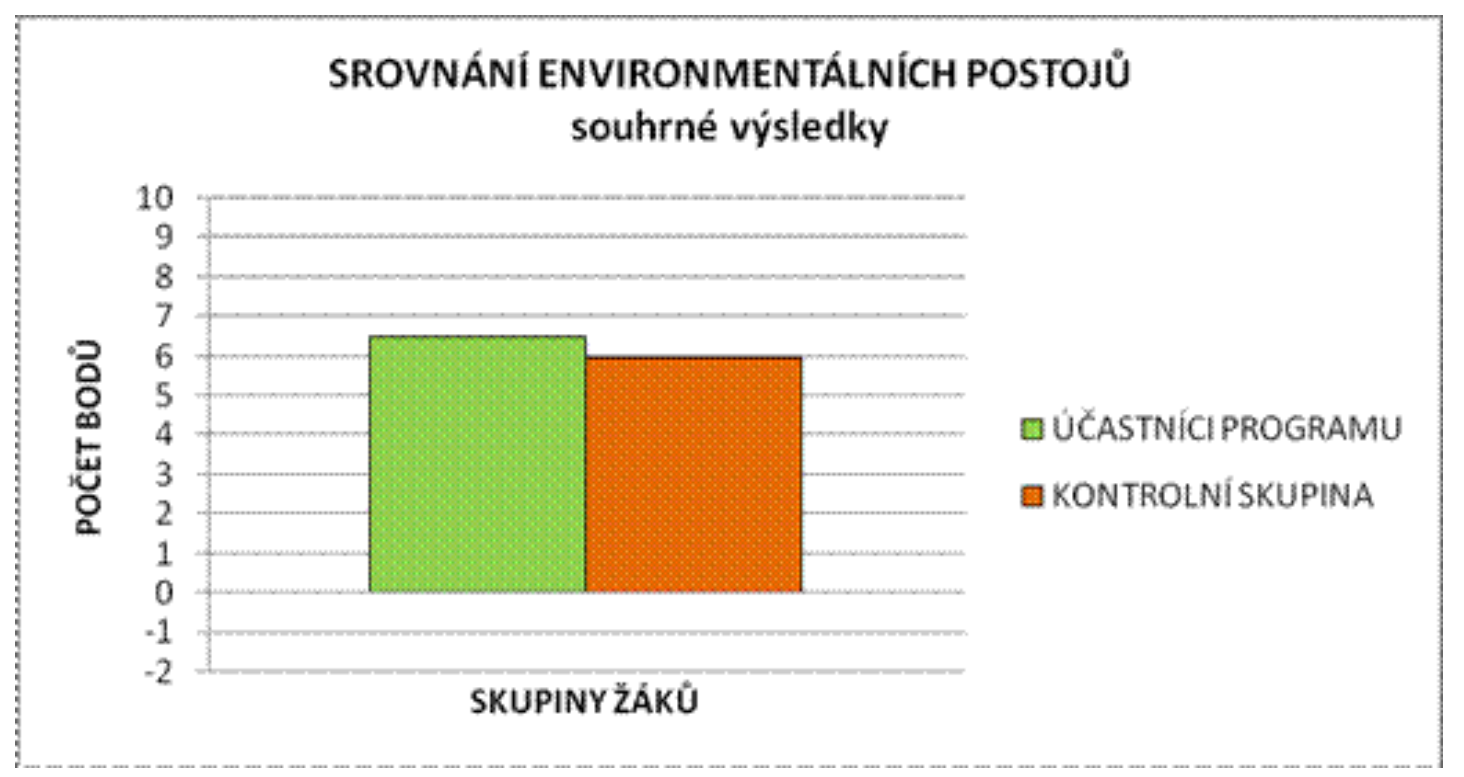

Obrázek 2.

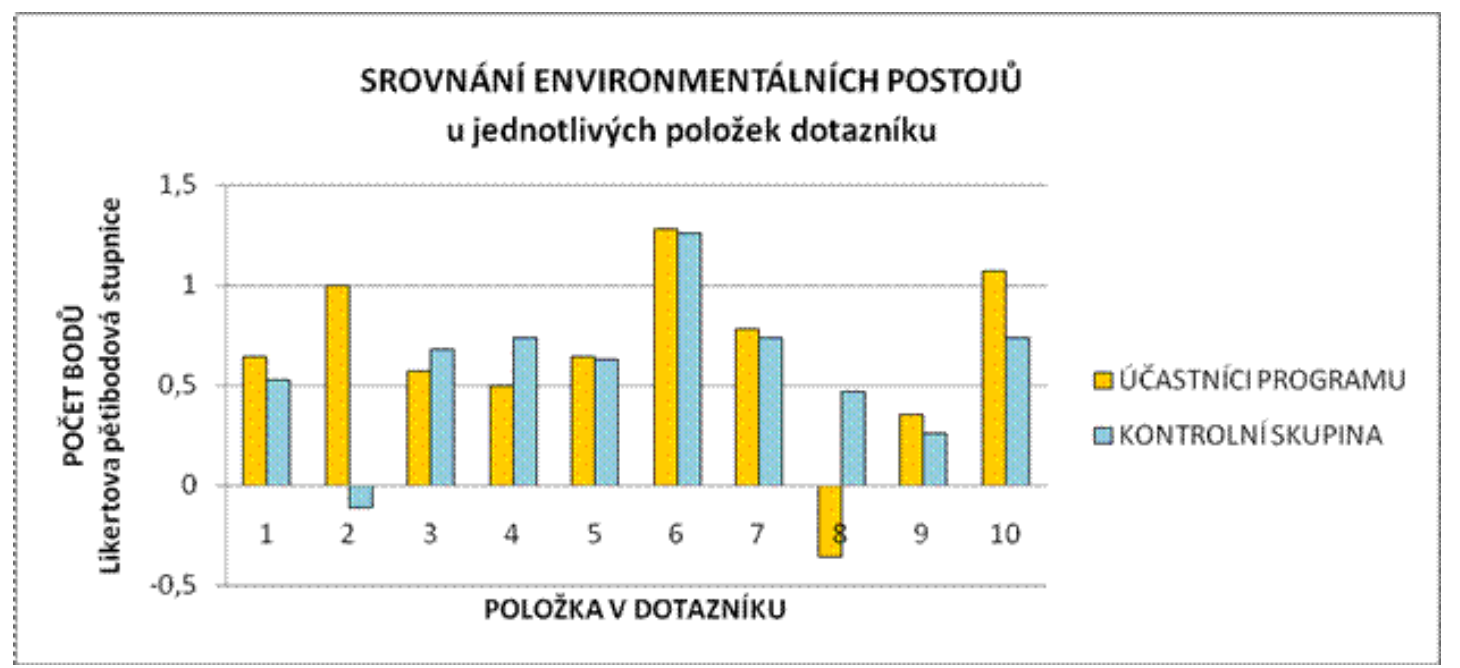




\section{Diskuze}

Vzhledem k malému počtu účastníků programu a rovněž i žáků kontrolní skupiny nelze z výsledků vyvozovat žádné obecné závěry.

HO: Žáci, kteří se zúčastnili výukového programu Ochránci planety, zastávají častěji proenvironmentální postoje než studenti, kteří se programu nezúčastnili.

Hypotéza HO se nepotvrdila, rozdíly v environmentálních postojích jsou velmi malé.

$H 1(H 3, H 4, H 5, H 6, H 7, H 9, H 10)$ : Žáci, kteří se zúčastnili výukového programu Ochránci planety, zastávají u tvrzení $1(3,4,5,6,7,9,10)$ častěji proenvironmentální postoj než studenti, kteří se programu nezúčastnili.

Hypotézy $\mathrm{H} 1$ (H3, H4, H5, H6, H7, H9, H10) se nepotvrdily, rozdíly v environmentálních postojích nejsou statisticky významné.

H2: Žáci, kteří se zúčastnili výukového programu Ochránci planety, zastávají u tvrzení 2 častěji proenvironmentální postoj než studenti, kteří se programu nezúčastnili.

Hypotézu H2 se nepodařilo vyvrátit, žáci, kteří se zúčastnili programu, se častěji přikláněli k názoru: "I já svým chováním poškozují životní prostředí."

H8: Žáci, kteří se zúčastnili výukového programu Ochránci planety, zastávají u jednotlivých tvrzení 8 častěji proenvironmentální postoj než studenti, kteří se programu nezúčastnili.

Nejen, že hypotéza H8 nebyla potvrzena, navíc se ukázalo, že nesouhlas s tvrzením "Moje jednání nemá žádný zásadní vliv na změny v ekosystémech na jiných světadílech.", vykazovala kontrolní skupina častěji než účastníci programu.

Vzhledem k malému souboru dat není potřeba obsáhle diskutovat o relevantnosti výsledků. Toto šetření Ize považovat za pilotáž evaluační metody výukového programu v oblasti environmentálních postojů. Přesto, že výsledky naznačují, že by výukový program Ochránci planety mohl přispívat k uvědomění si, že i já, jako jedinec, poškozuji životní prostředí, je potřeba vytvořit si reprezentativní kontrolní skupinu, kde budou zohledněny i jiné vlivy na environmentální postoje.

V případě, že bychom se měli zabývat otázkou, proč se v ostatních položkách neprojevil významný rozdíl mezi účastníky programu a kontrolní skupinou, mưžeme hledat chyby jednak $v$ samotné tvorbě výukového programu, dále $v$ chybné metodice výzkumu nebo $v$ chybě při realizaci evaluace. Je velmi náročné formulovat tvrzení, která by postihovala oblast afektivních cílů environmentální výchovy - navíc pro věkovou skupinu žáků navštěvujících základní školu. Některá tvrzení mohou být sporadická, a mohli bychom namítnout, že pomocí nich nelze měřit proenvironmentální postoje. Otázkou je, co si pod jednotlivými položkami představí dospělí lidé a co žáci základních škol, u kterých nemůžeme předpokládat široký rozhled a celistvé informace $z$ dané problematiky.

U kontrolní skupiny se objevily tři výsledky (viz Tab. 4), které bychom mohli považovat za odlehlé, ale vzhledem k malému počtu dat není možné je vyloučit. $Z$ těchto důvodů Ize považovat za chybu nereprezentativní vzorek v kontrolní skupině. 


\section{Závěr}

Cílem výzkumu byla evaluace výukového programu Ochránci planety, zejména $\checkmark$ oblasti změn environmentálních postojů. Šetření poukázalo na některé nedostatky $\mathrm{v}$ metodice. Přesto není potřeba $v$ tuto chvíli metodu evaluace zcela zavrhovat. Výzkum bude pokračovat i nadále. V první řadě zajistíme reprezentativní vzorek kontrolní skupiny, kde budou zohledněny i jiné vlivy na environmentální postoje žáků a současně s tím bude dále pokračovat práce na tvorbě a zlepšování výukového programu. Po provedení nového statistického vyhodnocení budeme snad schopni lépe zhodnotit možnost využití dotazníku "Jaký je můj názor?", tj. upravené rozšířené NEP/DSP škály proenvironmentálních postojů pro evaluaci dosažení afektivních cílů výukových programů environmentální výchovy. V současné době Ize šetření považovat pouze za pilotáž navrhované metody evaluace. Bylo upozorněno na možné chyby v metodice výzkumu, ale zároveň je třeba zdůraznit, že se jedná o metodu, která není náročná na organizaci v rámci realizace výukového programu. Může tedy posloužit jako inspirace k provádění kritického zhodnocení toho, zda předem stanovené cíle byly dosaženy.

\section{Literatura}

- Činčera, J., \& Štěpánek, P. (2007). Výzkum ekologické gramotnosti studentů středních odborných škol. Envigogika, 2(1), 2007-12. Retrieved from http://www.envigogika.cuni.cz/index.php/Envigogika/article/view/12 http://dx.doi.org/10.14712/18023061.12

- Dvořáková, M. (2007) Hodnocení ve vyučování. In Pedagogika pro učitele (pp. 243-262). Praha: Grada Publishing, a.s..

- EAGLES Paul F J, , \& Robert, D. (1999). Factors Influencing Children's Environmental Attitudes. The Journal of Environmental Education, 0095, 33-37. http://dx.doi.org/10.1080/00958969909601882

- Hakr, T. (2005). Earth Education : Výchova o Zemi. Liberec: Technická univerzita v Liberci, Pedagogická fakulta. Retrieved from http://www.fp.tul.cz/env/st prace.php

- Johnson, B. (2004). Connecting Outdoor Learning Experiences to Our Schools and Our Homes : An International Study of Teachers' Understandings of Energy in Ecological Systems and In Our Lives. School of Outdoor Education \& Environment. Paper presented at International Outdoor Education Research Conference. Retrieved from http://www.latrobe.edu.au/oent/OE conference 2004/2004 conference papers.html

- Tbilisi Declaration (1977). . Retrieved from http://www.gdrc.org/uem/ee/tbilisi.html

- Van Matre, S. (1999). Earth Education : A New Beginning. 4th edition. Greenville, W. Va., U.S.A: The Institute for Earth Education.

- Van Matre, S. (1979). Sunship Earth : An Earth Education Program Getting to Know Your Place in Space. 1st edition. Martinsville, IN, USA: American Camping Association.

- Van Matre, S., \& Johnson, B. (1988). Earthkeepers : Four Keys for Helping Young People Live in Harmony with the Earth. 1st edition. Warrenville, USA: The Institute for Earth Education.

\section{Recenzní posudek (slovní hodnocení příspěvku)}

Recenzent nesouhlasí se zveřejněním jména.

"Článek si klade aktuální otázku evaluace programů environmentální výchovy. Je zapotřebí vyzdvihnout poctivost při kritickém hodnocení nedostatků výzkumu a úsilí 
o nesnadné postižení úspěšnosti dosahování afektivních vzdělávacích cílů. Autor výsledky šetření nepřeceňuje, i když navržená metoda komparace dvou nezávislých skupin respondentů svědčí o kvalitně koncipovaném výzkumu.

Poněkud překvapivé výsledky, dokládající pouze zanedbatelný rozdíl, který vykazovali absolventi kurzu oproti kontrolní skupině žáků, nabízejí různé závěry:

1. ,chyba' je v samotném kurzu environmentální výchovy, který neplní stanovené cíle,

2. problém je ve výzkumném nástroji a navržené metodice, které nejsou vhodné pro evaluaci výukového kurzu,

3. problém vznikl při realizaci výzkumu, což je závěr, který činí autor (nedostatečná kontrolní skupina). $V$ takovém případě ovšem nelze hodnotit ani navrženou metodu zkoumání a je obtížné souhlasit s celkovým vyzněním př́íspěvku: ,...ukázalo se, že v případě zajištění reprezentativního vzorku kontrolní skupiny by bylo možné metodu za pomoci dotazníku Jaký je můj názor?, tj. upravené, rozšířené NEP/DSP škály proenvironmentálních postojů, použít pro evaluaci dosažení afektivních cílů výukových programů environmentální výchovy.'

I když výzkumný nástroj vychází z již testovaného dotazníku pro měření environmentální gramotnosti, je možné pochybovat o schopnosti některých výroků měřit proenvironmentální postoje.

Např. výrok: ,Nové vynálezy zachrání Zemi před dalšími ekologickými katastrofami.' Předpokládá se, že nesouhlas $\mathrm{s}$ tímto výrokem je vyjádřením žádoucího efektu environmentální výchovy? Vždyt technické inovace, alternativní zdroje energie (projekt ITER) atd. jsou neodmyslitelnou součástí rešení globálních problémů životního prostředí. ,Nezachrání' sice Zemi samy o sobě, ale stejně tak Ize, při předpokládaném růstu populace, pochybovat o úspěšných strategiích udržitelného rozvoje, které by nezahrnovaly vědecký pokrok. Podobně by bylo možné polemizovat s výrokem č.6, případně podezírat výrok č.1 z implikování odpovědi.

Pokud nebylo provedeno dostatečně kvalitní měření, bylo by vhodnější neposuzovat ani adekvátnost výzkumného nástroje.

Celkově se jedná o zajímavý pokus o hodnocení úspěšnosti výukového programu a je jen škoda, že výsledky nemají dostatečnou vypovídací schopnost. Rozhodně ale může sloužit jako podnět $\mathrm{k}$ dalšímu zkoumání $v$ dané oblasti." 
Časopis Envigogika vydává Centrum pro otázky životního prostředí UK. Vývoj časopisu je podpořen projektem OP VK Mezioborová sít udržitelného rozvoje.

Více najdete na internetových stránkách projektu mosur.czp.cuni.cz
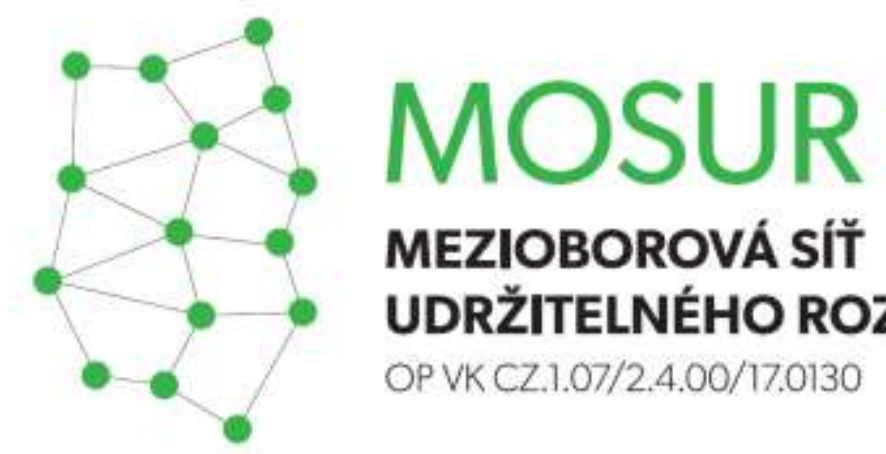

\section{MEZIOBOROVÁ SÍT} UDRŽITELNÉHO ROZVOJE

OP VK CZ.1.07/2.4.00/17.0130
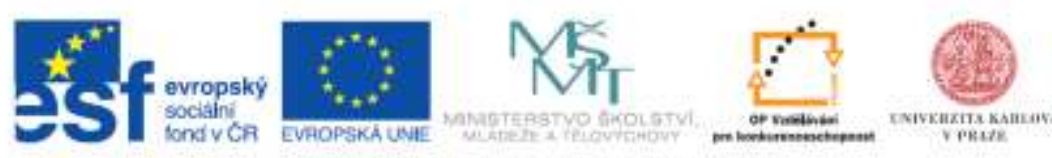

INVESTICE DO ROZVOJE VZDELAVANI 